\title{
When the North Last Headed South: Revisiting the 1930s
}

\begin{abstract}
The U.S. recession of 2007-09 is unique in the post-World War II experience in the broad company it kept. Activity contracted around the world, with the advanced economies of the North experiencing declines in spending more typical of the developing economies of the South for the first time since the 1930s. This paper examines the role of policy in fostering recovery in that earlier decade. With nominal short-term interest rates already near zero, monetary policy in most countries took the unconventional step of delinking currencies from the gold standard. However, analysis of a sample that includes developing countries shows that this was not as universally effective as often claimed, perhaps because the exit from gold was uncoordinated in time, scale, and scope and, in many countries, failed to bring about a substantial depreciation against the dollar. Fiscal policy was also active-most countries sharply increased government spending-but was prone to reversals that may have undermined confidence. Countries that more consistently kept spending high tended to recover more quickly.
\end{abstract}

he financial and economic dislocations of the past two years have been
sharp and widespread. Yet there is ample precedent for such crises-
and for the economic adjustment that follows to be wrenching. Among the
advanced economies, those earlier crises occurred either before World
War II or in open economies that were out of sync with the global cycle. ${ }^{1}$
Crashes and severe contractions have been more common in emerging
market economies. In the current episode, however, activity collapsed in
unison in developed and developing countries around the world. Indeed,

1. Reinhart and Rogoff (2009) provide many comparisons and a full explanation of the data. 
the rarity of current circumstances is why we rely on an event three-quarters of a century old, the Great Depression, as the main comparator. ${ }^{2}$

Given the importance of that precedent in understanding the current contraction, it is useful to cast a sharp focus on the role that policy actions played in shaping recovery in the 1930s. Unconventional monetary policy action has been called (Svensson 2003) a "foolproof way" of preventing deflation, especially in an open economy that can generate additional demand through depreciation of its currency. But when the global pie is shrinking, such action may be less effective. In the 1930s, moving off the gold standard bought fiscal authorities in many countries more space for stimulus because their central banks had room on their balance sheets to purchase more government securities and to generate additional income. It also allowed each country to devalue relative to gold. ${ }^{3}$ Those actions, however, were mostly uncoordinated in time, scale, and scope. As a consequence, the record of success among countries abandoning the gold standard, both in avoiding a severe contraction and in speeding the recovery, is quite mixed. The 1930s also saw massive increases in government spending in many countries, but fiscal authorities were prone to reverse themselves. As a result, some of the direct benefits of that spending were offset by harmful effects stemming from its volatility.

\section{The Appropriate Precedent}

The Business Cycle Dating Committee of the National Bureau of Economic Research has put the peak of the current U.S. cycle at the end of 2007. There is no equivalent formalism at the world level, but indicators for most other countries started turning down about six months later, consistent with the view that the United States led the way down. Robert Barro and José Ursúa (2008) have demonstrated that occasional large, adverse shocks hit national economies without the reason for those shocks always being clear. The current episode is particularly unusual because so many economies around the world contracted simultaneously.

Table 1 provides a historical perspective on the rarity of events like those of recent years, by documenting changes in real exports during past systemic crises from 1890 to today, for samples ranging from 35 to 111 countries. The episodes included in the table are those that saw spikes in the number

2. Eichengreen and O'Rourke (2009) provide useful comparisons to that episode as well.

3. This strategy is discussed in Eichengreen (1992) and Romer (1992). 
Table 1. Declines in Real Exports during Crisis Episodes

\begin{tabular}{|c|c|c|c|c|c|c|}
\hline \multirow[b]{2}{*}{ Episode } & \multirow[b]{2}{*}{ Year } & \multirow[b]{2}{*}{$\begin{array}{c}\text { No. of } \\
\text { countries }\end{array}$} & \multicolumn{2}{|c|}{$\begin{array}{c}\text { Countries } \\
\text { experiencing real } \\
\text { export decline } \\
\text { (percent of total) }\end{array}$} & \multirow[b]{2}{*}{$\begin{array}{l}\text { Largest } \\
\text { decline } \\
\text { (percent) }\end{array}$} & \multirow[b]{2}{*}{$\begin{array}{l}\text { Median } \\
\text { change } \\
\text { (percent) }\end{array}$} \\
\hline & & & Any & $\begin{array}{c}\text { Greater } \\
\text { than } \\
15 \text { percent }\end{array}$ & & \\
\hline \multirow[t]{2}{*}{ Barings crisis } & 1890 & 35 & 34.3 & 5.2 & -18.0 & 2.2 \\
\hline & 1891 & 35 & 57.1 & 8.6 & -47.5 & -1.0 \\
\hline \multirow[t]{2}{*}{ Panic of 1907} & 1907 & 73 & 31.5 & 4.1 & -27.4 & 6.9 \\
\hline & 1908 & 75 & 66.7 & 20.0 & -33.6 & -5.4 \\
\hline \multirow[t]{2}{*}{ Commodity crash } & 1920 & 70 & 48.6 & 31.4 & -60.9 & 1.4 \\
\hline & 1921 & 73 & 76.7 & 54.8 & -73.7 & -19.8 \\
\hline \multirow[t]{4}{*}{ Great Depression } & 1929 & 94 & 43.6 & 13.8 & -36.2 & 1.3 \\
\hline & 1930 & 94 & 88.3 & 48.9 & -51.2 & -13.9 \\
\hline & 1931 & 95 & 100.0 & 88.4 & -73.5 & -33.3 \\
\hline & 1932 & 95 & 80.0 & 62.1 & -53.8 & -17.1 \\
\hline Sterling crisis & 1967 & 104 & 48.5 & 23.3 & -92.0 & 0.4 \\
\hline $\begin{array}{l}\text { End of Bretton } \\
\text { Woods regime }\end{array}$ & 1973 & 111 & 11.7 & 4.5 & -79.4 & 39.1 \\
\hline First oil shock & 1975 & 110 & 41.8 & 29.1 & -78.3 & 1.8 \\
\hline \multirow{2}{*}{$\begin{array}{l}\text { Latin American } \\
\text { debt crisis }\end{array}$} & 1981 & 106 & 60.4 & 31.1 & -70.7 & -3.6 \\
\hline & 1982 & 108 & 62.3 & 29.2 & -77.2 & -4.0 \\
\hline Nordic crises & 1991 & 93 & 57.0 & 26.9 & -75.8 & -1.4 \\
\hline $\begin{array}{l}\text { Exchange Rate } \\
\text { Mechanism crisis }\end{array}$ & 1992 & 95 & 36.8 & 14.7 & -65.6 & 3.9 \\
\hline Tequila crisis & 1995 & 105 & 23.8 & 11.4 & -79.3 & 9.4 \\
\hline \multirow{2}{*}{$\begin{array}{l}\text { Asia, Russia, } \\
\text { LTCM crises }\end{array}$} & 1997 & 109 & 40.4 & 13.8 & -83.8 & 2.8 \\
\hline & 1998 & 107 & 51.4 & 22.4 & -62.4 & -1.4 \\
\hline September 11 & 2001 & 108 & 74.1 & 28.7 & -39.8 & -9.6 \\
\hline \multirow[t]{2}{*}{ "Great Contraction" } & 2008 & 87 & 86.2 & 52.9 & -74.1 & -16.6 \\
\hline & $2009^{a}$ & 42 & 100.0 & 92.9 & -62.2 & -36.6 \\
\hline \multirow[t]{2}{*}{ Averages } & 1890-1939 & 70 & 41.1 & 18.0 & -82.2 & 4.5 \\
\hline & 1957-2008 & 99 & 33.0 & 14.6 & -92.0 & 9.2 \\
\hline
\end{tabular}

Sources: Reinhart and Rogoff (2009, appendix A); League of Nations, Statistical Yearbook, various issues; national sources; Maddison (2004); Mitchell (2003a, 2003b, 2003c).

a. Through April.

b. LTCM, Long Term Capital Management, the large hedge fund that failed in 1998.

of banking crises worldwide, as reported by Carmen Reinhart and Kenneth Rogoff (2009). As is evident from the table, it is not unprecedented for a majority of countries to experience declines in real exports coincident with systemic financial crises. Many of the median changes listed in the last column are negative, and the largest declines (which the preceding column reports for each country) are quite large indeed. The scale of the most recent 
experience, however, has only one precedent, namely, the early 1930s: more than four-fifths of countries in both periods saw contractions in exports of greater than 15 percent. The scope of the problem also distinguishes the Great Depression and the current, second "Great Contraction": only in those two episodes did virtually all of the nations of the world witness shrinking trade flows. No other crisis period in the past century matches that experience.

The commonality of the experience in these two episodes makes an examination of the setting of policy in the 1930s relevant for consideration today. We consider the actions of the monetary and those of the fiscal authorities in turn.

\section{Monetary and Exchange Rate Policy during the Great Depression}

The painful adjustment in activity around the world during the early 1930s strained the confidence of many public officials in the speed with and extent to which the market system would correct itself. As a consequence, the range of policy response was wide. The major form that monetary policy experimentation took was to expand central bank balance sheets by lowering the gold content of the home currency. As will be discussed below, countries devalued relative to gold at different points over the decade and by different amounts. The mechanism through which this proved expansionary can best be understood by considering a single country's experience.

In the United States, the key decision in the early 1930s that shifted the stance of monetary policy decisively toward ease was not made by the nation's principal monetary authority, the Federal Reserve. Rather, it was the devaluation of the dollar in terms of gold by newly inaugurated President Franklin Roosevelt, ${ }^{4}$ followed by a sharp increase in gold inflows as a result of political instability in Europe, that produced a marked relaxation of monetary conditions, through a large increase in high-powered money. ${ }^{5}$ As shown in figure 1, high-powered money in the United States (essentially, currency in circulation, vault cash, and bank deposits with the Federal Reserve) increased by 60 percent from March 1933 to May 1937 (the trough

4. There were two steps in this process. Executive Order 6102 in April 1933 lowered the gold content of the dollar and prohibited the public from holding gold. The value of the dollar in terms of gold was lowered again with the Gold Reserve Act of 1934.

5. Eichengreen (1992), Romer (1992), and Bernanke (2004) explain the mechanics. Important earlier contributions include Choudhri and Kochin (1980) and Hamilton (1988). 
Figure 1. Monetary Conditions in the United States, 1929-39
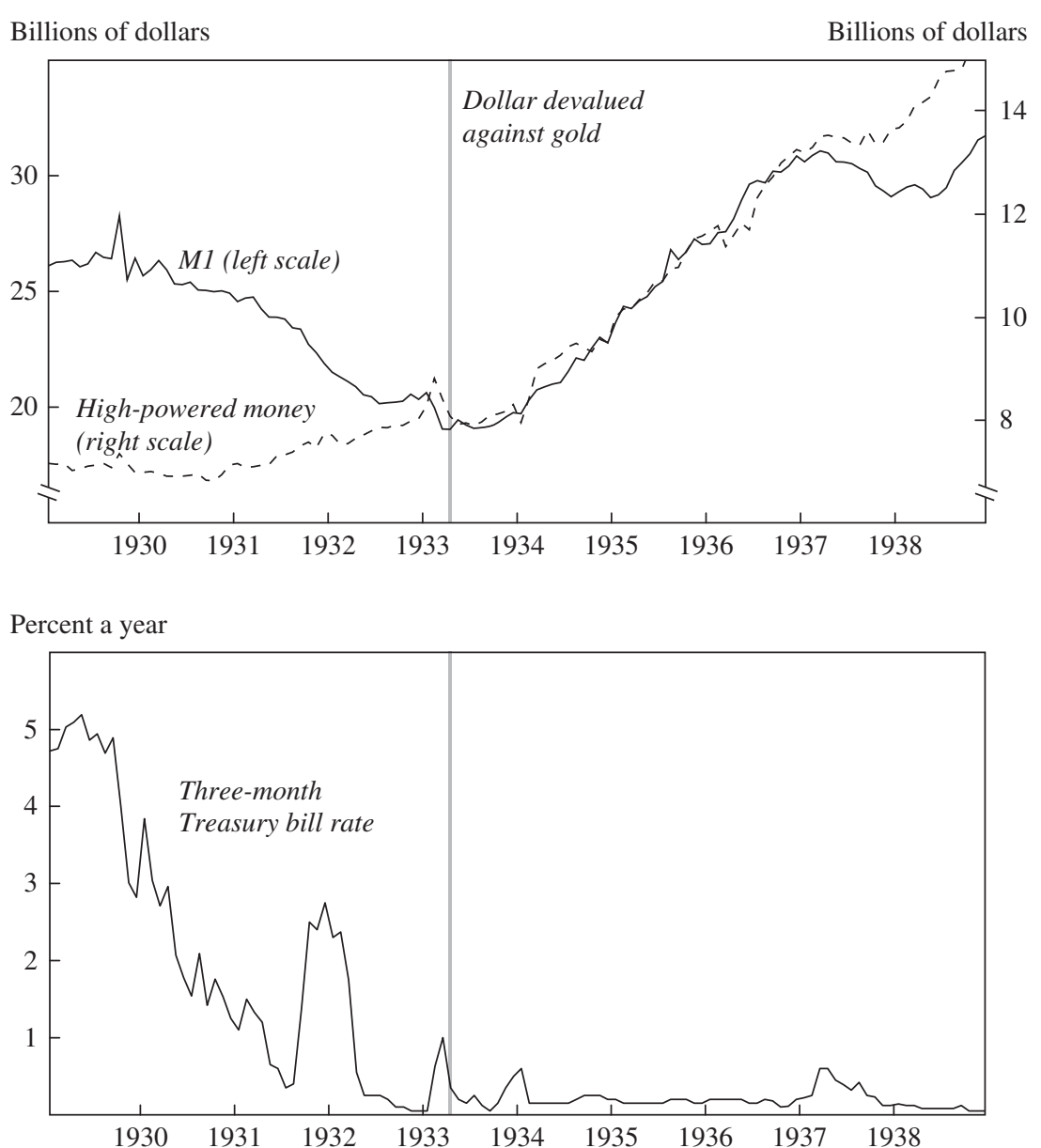

Sources: Friedman and Schwartz (1963, tables A.1 and B.3); Board of Governors of the Federal Reserve System (1943, pp. 439-42 and 448-451).

and peak, respectively, of the business cycle); the M1 measure of the money supply expanded by about the same amount from 1933 to 1937 . Short-term nominal interest rates, proxied in the bottom panel by the three-month Treasury bill rate, were already close to zero. Thus, in the decade from 1932 onward, policy impetus cannot be measured by reference only to the level of the short-term interest rate.

Then as now, the size and composition of the monetary authority's balance sheet had the potential to influence financial markets and the 
economy. An enlarged balance sheet also provided fiscal authorities more space to be aggressive, if they felt so inclined. ${ }^{6}$ All this meets the definition of "unconventional" monetary policy and quantitative easing (as in Bernanke and Reinhart 2004). In the standard rendering, there were three acts to this episode of quantitative easing.

In the first act, in 1932, U.S. policymakers extended their mistake of the prior three years of not addressing a crisis of confidence. After the stock market crash of 1929, the public sought to build up a cushion of safe assets. For households, this meant holding more currency; for banks, the demand for reserves rose. Declines in asset values and increased demand for liquidity strained the financial system, leading to a daisy chain of bank failures, which further heightened demand for safe assets. ${ }^{7}$ High-powered money did expand, but by too little to offset increases in desired currency and reserve holdings, as detailed by Milton Friedman and Anna Schwartz (1963) and by Philip Cagan (1965). ${ }^{8}$ In the second act, President Roosevelt's decision to devalue relative to gold in 1933 triggered an expansion in the monetary authority's balance sheet and sent a clear signal of the intent to reflate. ${ }^{9}$ In the final act, policymakers repeated their initial mistake and contracted policy by sterilizing gold inflows in 1936 and increasing reserve requirements in 1937, stalling the expansion of high-powered money. ${ }^{10}$ This third act highlights the danger of a premature exit from policy accommodation, as Christina Romer has recently pointed out. ${ }^{11}$ It is the middle act, the move off the gold standard, that has been most widely praised and that offers the best evidence that unconventional policy action can spur recovery.

6. Open market purchases of Treasury securities can lower yields on government debt if assets are imperfect substitutes for each other. Even if they are perfect substitutes, the swap of interest-bearing government debt for non-interest-bearing reserves works to lower debt service. Also, a decline in real interest rates improves measures of debt sustainability. Two issues arise, however. First, the macroeconomic effects will depend on whether the public capitalizes the income stream of central bank profits. Second, paying interest on reserves lessens the reduction in the debt burden associated with open market purchases.

7. James (2009) argues that these two episodes are distinct. The year 1929 marked a major asset revaluation, and 1931 was a year of banking collapse.

8. This failure can be explained as the Federal Reserve being either hamstrung by the gold standard (as argued in Eichengreen 1992) or focused too much on reserve supply rather than reserve demand (as in Meltzer 2003). Either case amounts to a lack of willingness to use the appropriate policy tools, not a lack of ability. Hsieh and Romer (2006) show that a short-lived monetary accommodation in 1932 did not trigger concerns in markets or among policymakers about a destabilizing exit from the gold standard.

9. Romer (1992) stresses the multiplier effects of the former; Eichengreen and Temin (2000) emphasize the change in the zeitgeist as rekindling inflation expectations.

10. Meltzer (2003) and Orphanides (2004) review this experience.

11. Christina D. Romer, "The Lessons of 1937," The Economist, June 18, 2009. 
But although the U.S. experience can be interpreted that way, the wider international record is more mixed.

Devaluing a nation's currency in terms of gold has three distinct effects. ${ }^{12}$ First, the home-currency value of the monetary authority's resources expands. If, as in the U.S. case in 1933, short-term interest rates are near the zero bound, this amounts to unconventional monetary policy. Second, if other countries remain at an unchanged gold parity (or devalue by less than the home country), the exports of the home country become priced more competitively on world markets. Third, devaluation might be interpreted as a regime switch, signaling higher inflation in the future and therefore working to lower real interest rates immediately.

Table 2 gives a year-by-year chronology of countries' exits from the gold standard during the 1930s, along with some information about the course of economic contraction and recovery in each country. The first column reports the year that output peaked-usually 1928 or 1929 . The second column reports the peak-to-trough decline in real output. This was, indeed, a wrenching contraction, with the 29 percent decline in the United States among the worst. Small open economies that were reliant on commodity production, such as Chile, Nicaragua, and Uruguay, were hit especially hard. Closed economies, such as Italy and Portugal, in contrast, fared better.

The last column in the table provides a metric for recovery: the number of years it took for output to return to the previous peak. This seems an intuitive way to measure a downturn, but it is also quite conservative. Ongoing expansion in potential output implies that a return to prerecession output is not synonymous with an elimination of economic slack. What is striking in this column is how varied was the experience and how long was the typical path to recovery.

In the event, abandoning the gold standard was not a foolproof solution for economic recovery. Figure 2 plots for each country in table 2 the peakto-trough decline in real GDP against the number of years it took after 1929 for the country to devalue or leave the gold standard. There is no obvious association between the timing of the devaluation and the severity of the downturn. Early leavers (those in 1929 and 1930) experienced output contractions ranging from 13 to 36 percent. Late exiters (from 1933 onward) suffered output declines from 6 to 32 percent.

In his work with different coauthors on the interwar gold standard, Barry Eichengreen has argued that devaluation against gold was an engine

12. Eichengreen and Sachs (1986) work through the effects in a simple model. 
Table 2. Depth and Duration of the Great Depression by Year of Exit from the Gold Standard

\begin{tabular}{|c|c|c|c|}
\hline Country & $\begin{array}{l}\text { Year of business } \\
\text { cycle peak }\end{array}$ & $\begin{array}{l}\text { Peak-to-trough } \\
\text { decline in real } \\
\text { GDP per capita } \\
\text { (percent) }\end{array}$ & $\begin{array}{l}\text { Years until } \\
\text { return to } \\
\text { precrisis } \\
\text { real GDP }\end{array}$ \\
\hline \multicolumn{4}{|c|}{ December 1929 and 1930 exits from gold standard } \\
\hline Australia & 1926 & 17.3 & 10 \\
\hline New Zealand & 1929 & 17.8 & 7 \\
\hline Argentina & 1929 & 19.4 & 15 \\
\hline Brazil & 1928 & 13.3 & 8 \\
\hline Uruguay & 1929 & 36.1 & 17 \\
\hline Venezuela & 1929 & 24.1 & 6 \\
\hline \multicolumn{4}{|c|}{1931 exits from gold standard } \\
\hline United Kingdom & 1929 & 6.6 & 5 \\
\hline Austria & 1929 & 23.4 & 10 \\
\hline Canada & 1928 & 29.0 & 12 \\
\hline Finland & 1929 & 6.1 & 5 \\
\hline Germany & 1928 & 17.8 & 7 \\
\hline Japan & 1929 & 9.3 & 4 \\
\hline Norway & 1929 & 1.9 & 3 \\
\hline Sweden & 1930 & 4.8 & 4 \\
\hline Chile & 1929 & 46.6 & 16 \\
\hline El Salvador & 1928 & 11.3 & 9 \\
\hline Hungary & 1929 & 11.4 & 7 \\
\hline India & 1929 & 8.2 & 31 \\
\hline Korea & 1928 & 12.7 & 5 \\
\hline Malaya $^{\mathrm{b}}$ & 1929 & 17 & 35 \\
\hline Mexico & 1929 & 31.1 & 16 \\
\hline Portugal & 1929 & 2.4 & 2 \\
\hline \multicolumn{4}{|c|}{1932 exits from gold standard } \\
\hline Colombia & 1929 & 3.8 & 3 \\
\hline Costa Rica & 1928 & 15.7 & 9 \\
\hline Greece & 1930 & 6.4 & 4 \\
\hline Nicaragua & 1929 & 43.0 & 24 \\
\hline Peru & 1929 & 25.4 & 6 \\
\hline Romania & 1931 & 8.0 & 7 \\
\hline \multicolumn{4}{|c|}{1933 exits from gold standard } \\
\hline United States & 1929 & 28.9 & 10 \\
\hline Guatemala & 1930 & 23.6 & 6 \\
\hline Honduras & 1931 & 32.0 & 36 \\
\hline Philippines & 1929 & 13.1 & 8 \\
\hline \multicolumn{4}{|c|}{1934 exits from gold standard } \\
\hline Italy & 1929 & 6.4 & 6 \\
\hline \multicolumn{4}{|c|}{1935 exits from gold standard } \\
\hline Belgium & 1928 & 10.4 & 11 \\
\hline
\end{tabular}


Table 2. Depth and Duration of the Great Depression by Year of Exit from the Gold Standard (Continued)

\begin{tabular}{lccc}
\hline Country & $\begin{array}{c}\text { Year of business } \\
\text { cycle peak }\end{array}$ & $\begin{array}{c}\text { Pearough } \\
\text { decline in real } \\
\text { GDP per capita } \\
\text { (percent) }\end{array}$ & $\begin{array}{c}\text { Years until } \\
\text { return to } \\
\text { precrisis } \\
\text { real GDP }\end{array}$ \\
\hline France & 1936 exits from gold standard & \\
Netherlands & 1929 & 15.9 & 10 \\
Switzerland & 1929 & 16.0 & 21 \\
Netherlands East Indies & 1929 & 9.8 & 9 \\
Poland & 1929 & 14.3 & 9 \\
\hline
\end{tabular}

Sources: Reinhart and Rogoff (2009); Eichengreen (1992); League of Nations, Statistical Yearbook, various issues; Officer (2001); Maddison (2004); Mitchell (2003a, 2003b, and 2003c).

a. GDP is measured in 1990 international Geary-Khamis dollars.

b. Present-day Malaysia and Singapore.

c. Present-day Indonesia.

Figure 2. Timing of Exit from the Gold Standard and Severity of Output Decline, $1929-36^{\mathrm{a}}$

Peak-to-trough decline in real GDP per capita ${ }^{\mathrm{b}}$ (percent)

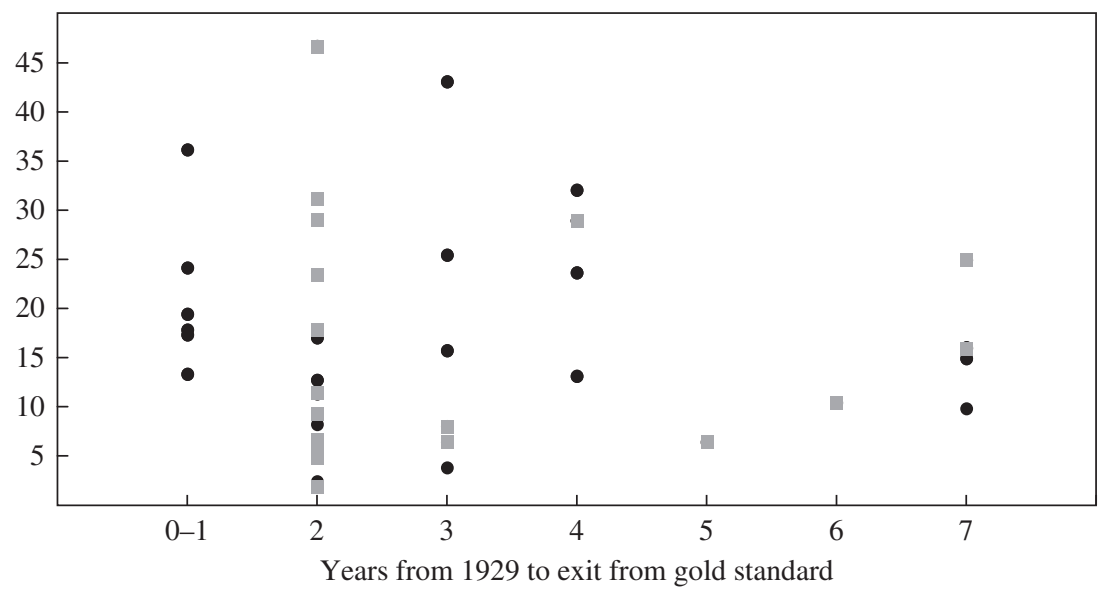

Sources: Reinhart and Rogoff (2009); Eichengreen (1992); League of Nations, Statistical Yearbook, various issues; Officer (2001); Maddison (2004); Mitchell (2003a, 2003b, 2003c).

a. Squares indicate countries in the original sample of 19 countries; circles indicate those in the expanded sample.

b. GDP is measured in 1990 international Geary-Khamis dollars. 
of reflation. ${ }^{13}$ The simple scatterplot in figure 2 suggests that the benefits were not always evident. But the figure implicitly differs from the prior literature in three ways: the choice of the measure of activity, the window of observation, and the country coverage; these differences can be addressed systematically.

Table 3 reports regressions that seek to explain various measures of economic recovery in the 1930s for different sets of countries. The first column reproduces what might be called "exhibit A" for those arguing that the change in the exchange rate regime was crucial in fostering economic recovery. That column, following the literature, relies on information collected in real time by the League of Nations. The change in industrial production from 1929 to 1937 for the 19 countries for which data are available from that source is regressed against the number of years after 1929 that the country exited the gold standard. For these 19 countries, leaving the gold standard had a statistically significant effect on industrial production over that common time period. Indeed, the coefficient on the timing variable is quite large. Leaving the gold standard at the start rather than at the end of the period prevented a decline in industrial output of more than one-half.

It might be argued that the more pronounced effect on industrial production in part reflects the higher cyclical amplitude of this narrower slice of economic activity. It could also be due to the greater dependence of manufacturing on international trade. The second column therefore repeats the exercise for the same countries but uses the change in real GDP per capita in place of the change in industrial production. The results, although smaller, remain statistically significant and quantitatively important for this broader measure of activity. According to this estimate, delaying the exit from the beginning to the end of this fixed window is associated with about a 20 percent loss in real GDP per capita.

The previous literature's use of the League of Nations sample puts particular weight on the experience of large countries and of countries in Europe. The third column therefore broadens the sample to include 39 countries, including many in Latin America. Although the coefficient on the timing variable remains negative, it is no longer statistically significant. Thus, some of the purported benefits of the 1930s regime switch are apparently sensitive to the country set.

In addition, because countries left the gold standard at different times, the literature's use of a single time period to measure recovery across that

13. See Eichengreen (1992), Eichengreen and Sachs (1985), and Eichengreen and Temin (2000). 


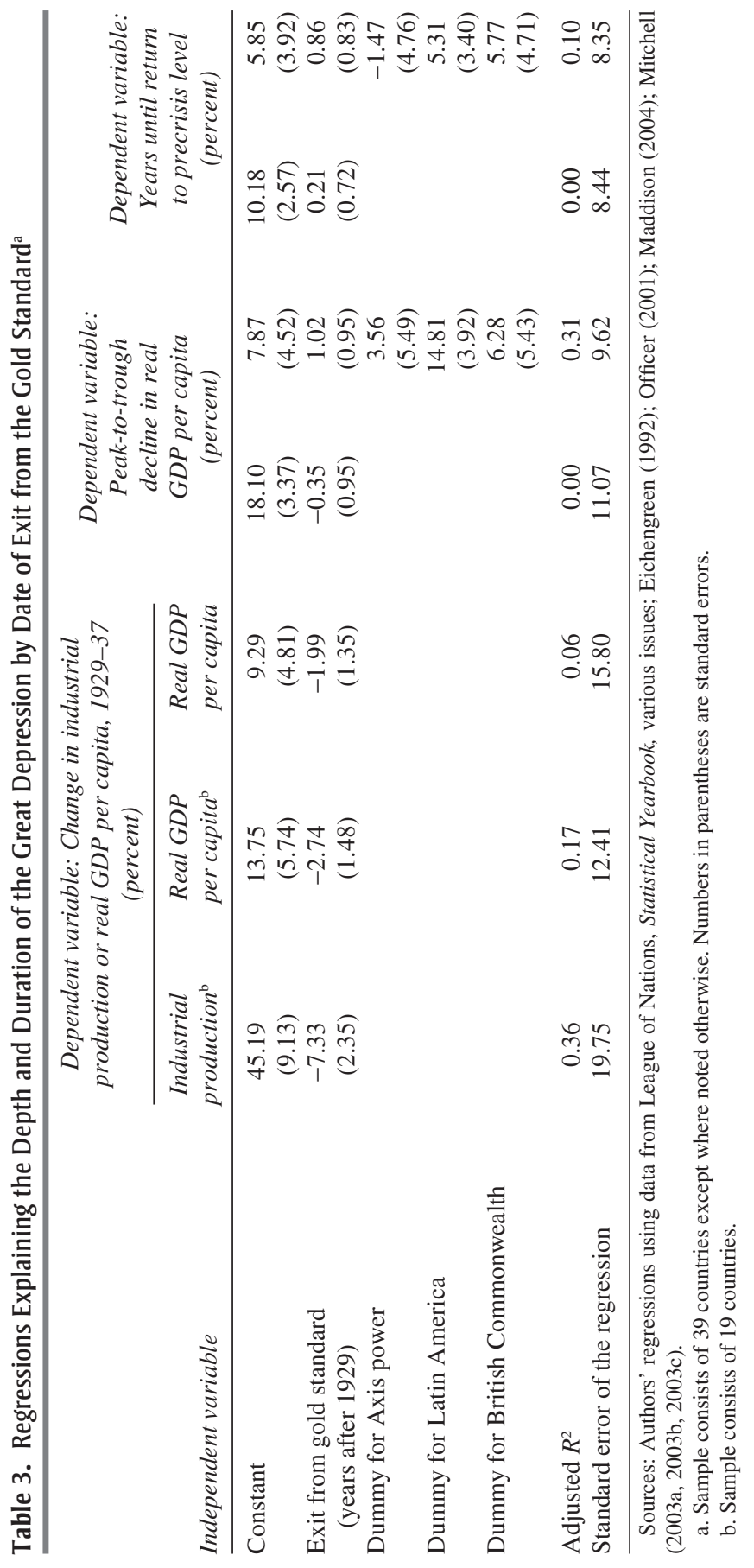


experience might be inappropriate. An alternative is to determine the width of the observation window country by country. We ran regressions using the date of exit from the gold standard to explain, first, the peak-to-trough decline in real GDP per capita (fifth and sixth columns in table 3), and second, the number of years it took for real GDP per capita to return to its precrisis level (final two columns). Because of the varied country set, the table reports both the simple regression using the date of exit and an augmented one that also includes dummy variables for whether the country was an Axis power, in Latin America, or a member of the British Commonwealth. In no case does the date of exit from the gold standard help to explain the depth or duration of the downturn, confirming the message from the earlier scatterplot.

All told, the evidence that countries exiting the gold standard early fared better is apparently fragile. Once one expands the sample to a broader set of countries and considers other measures of the business cycle, leaving the gold standard early was not always a reliable route to a shorter or less severe recession.

Why did exiting the gold standard generate so little benefit in the larger sample? The answer in part was already evident in table 2 . Countries left the gold standard at different times. Moreover, when they did leave, the range of variation in bilateral exchange rates vis-à-vis the U.S. dollar was wide, indicating that policymakers did not follow a common roadmap. The greatest number of countries left in 1931, but those that did so in 1932 adjusted by more. A few that moved to some form of floating arrangement saw their currencies unhelpfully appreciate against the dollar.

The important point for the United States is that almost all of these devaluations relative to gold produced an appreciation of the dollar, which added to the force of contraction domestically. Not until 1933 was some of that force pushed back, and even then the dollar still appreciated against the currencies of many economies. For contemporaneous observers, these swings in bilateral exchange rates smacked of "beggar thy neighbor" policy. From that experience was born a mistrust of floating exchange rates and a desire for a more managed system, famously expressed by Ragnar Nurkse (1944), among others. The net effect of these currency changes was to worsen the external drag on the U.S. economy, exactly when the appropriate policy was to reflate.

Some sense of the net external drag can be gotten from figure 3, which plots effective exchange rate indices between the United States and five country groups. The base is set to 100 in 1929, and the shaded area represents the range from plus to minus 15 percent of that parity. There are 
Figure 3. Exchange Rates of Selected Country Groups against the U.S. Dollar, 1929-38

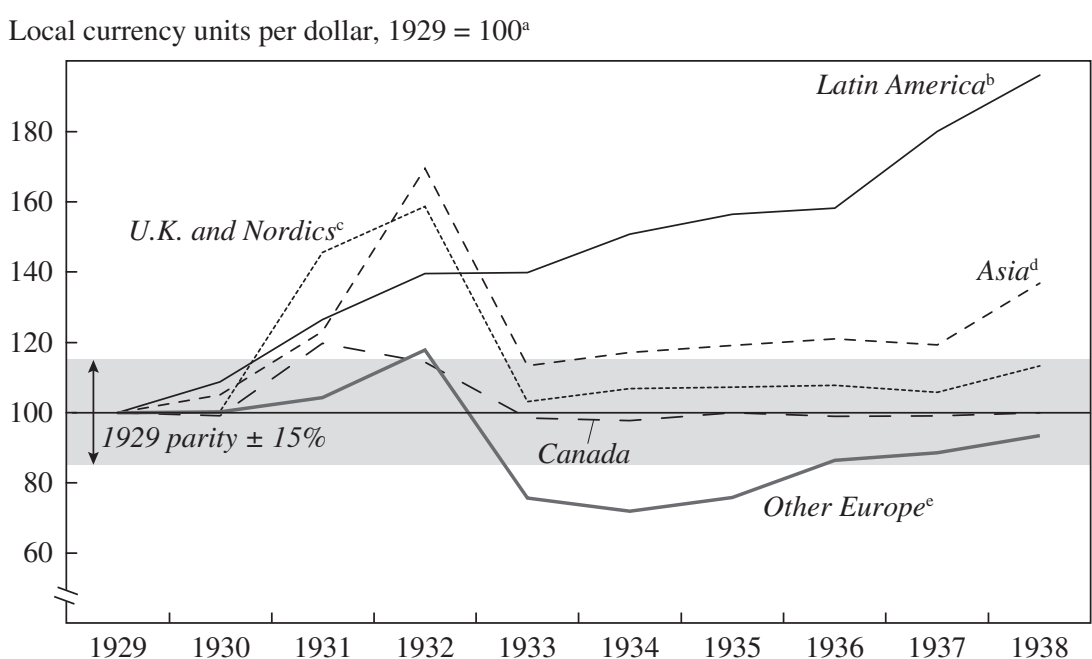

Sources: Reinhart and Rogoff (2009) and sources cited therein; authors calc ulations.

a. Each index is calculated from the simple unweighted average for the countries in the group.

b. Argentina, Brazil, Chile, Colombia, Costa Rica, El Salvador, Guatemala, Honduras, Mexico, Nicaragua, Peru, Uruguay, and Venezuela.

c. Finland, Norway, Sweden, and United Kingdom.

d. China, India, Japan, Korea, Netherlands East Indies, Philippines, Sri Lanka, Taiwan, and Thailand.

e. Austria, Belgium, France, Germany, Greece, Hungary, Italy, Netherlands, Poland, Portugal, and Romania.

three main messages. First, the range of variation of nominal exchange notes was fairly narrow, except in Latin American countries, suggesting that external relative price adjustment was not the crucial means of rebalancing. Second, Canada's vaunted embrace of floating exchange rates produced a result suggestive of considerable management in that market outcome. ${ }^{14}$ Third, most of the lines follow a track above 100 (that is, an appreciation of the U.S. dollar), implying that exchange rates worked to offset some of the domestic U.S. monetary policy stimulus.

This brings to mind Robert Mundell's (1968) insights about the $N+1$ currency problem. In a system of $N+1$ floating exchange rates, depreciation of the $N$ currencies must come from an appreciation of the $N+1$ currency. This creates a need for the economy using that anchor currency to overcompensate with domestic stimulus for that force of external restraint. The advantage of the gold standard was that all $N$ could cheapen their currencies without putting a special burden on any one nation, given that the $N+1$

14. Indeed, "fear of floating" in the Calvo and Reinhart (2002) sense seems evident. 
price was the value of gold. In the event, however, the adjustment was not so smooth.

\section{Fiscal Policy during the Great Depression}

Sustained fiscal impetus in the major countries was similarly needed in the 1930s. And it was tried in many countries, but seldom consistently. Indeed, in many cases fiscal policy contracted as the national economy shrank, worsening the downturn. This record of policymaking is summarized in table 4, which reports for a group of 30 countries the year in which economic activity hit its cyclical low, as well as real government spending in that year, indexed so that the 1929 level equals $100 .{ }^{15}$ We rely on government spending to measure the fiscal impetus, rather than the more commonly used budget balance, for two reasons. First, revenue typically falls off in economic contractions, irrespective of policy intent, thus worsening the fiscal balance without necessarily providing much impetus. Second, we are somewhat more confident about the reliability of spending data over time and across countries than about that of revenue (see Kaminsky, Reinhart, and Végh 2005).

The countries in table 4 are listed according to the co-movement of government spending and the economic cycle, from the most procyclical to the most countercyclical. Quite clearly, fiscal policy sometimes imparted considerable restraint rather than stimulus. As the third column shows, real government spending contracted in at least one year in 24 of the 30 countries, sometimes by a large amount.

The United States was not among the countries where the trend of real government spending amplified the business cycle: by the trough in 1933, real government spending was almost twice its level of 1929. Figure 4 plots real government spending in the United States and Canada, again indexed to 100 in 1929. There were three distinct episodes of large increases in spending, first at the end of President Herbert Hoover's administration in

15. Because of data limitations inherent in a large historical sample, the table uses statistics on central government spending only, which is problematic for countries with a federal system that allows discretion at the state or province level, such as the United States and Argentina, among others. Local budgetary pressures may have necessitated spending retrenchment that offset federal impetus. An additional issue is that real government spending is constructed using nominal spending from Mitchell (2003a, 2003b, 2003c), deflated by available price indexes. Again this is done for comparability across countries, but these measures do not always align well with readings from the national income and product accounts, where available. 
Table 4. Real Government Spending in Selected Countries, 1929-36

\begin{tabular}{|c|c|c|c|c|}
\hline Country & $\begin{array}{l}\text { Year of } \\
\text { trough in } \\
\text { real GDP } \\
\text { per capita }\end{array}$ & $\begin{array}{c}\text { Real } \\
\text { government } \\
\text { spending } \\
\text { at trough } \\
(1929=100)\end{array}$ & $\begin{array}{l}\text { Largest } \\
\text { annual } \\
\text { decline in } \\
\text { real spending } \\
\text { (percent) }\end{array}$ & $\begin{array}{c}\text { Year of } \\
\text { largest } \\
\text { decline in } \\
\text { real spending }\end{array}$ \\
\hline Chile & 1932 & 53.0 & 34.4 & 1932 \\
\hline Peru & 1932 & 55.7 & 25.7 & 1932 \\
\hline Venezuela & 1932 & 73.8 & 33.2 & 1931 \\
\hline Finland & 1932 & 79.4 & 28.7 & 1932 \\
\hline Austria & 1933 & 79.9 & 21.8 & 1933 \\
\hline Germany & 1932 & 94.1 & 9.8 & 1931 \\
\hline Netherlands East Indies & 1934 & 94.9 & 4.0 & 1931 \\
\hline Brazil & 1931 & 96.4 & 15.4 & 1931 \\
\hline Mexico & 1932 & 96.9 & 7.2 & 1931 \\
\hline Japan & 1931 & 99.7 & 8.9 & 1931 \\
\hline Colombia & 1931 & 102.0 & 32.7 & 1929 \\
\hline Norway & 1931 & 105.5 & None & None \\
\hline New Zealand & 1932 & 106.1 & 3.7 & 1932 \\
\hline Argentina & 1932 & 110.2 & 3.9 & 1931 \\
\hline Uruguay & 1933 & 110.7 & 13.3 & 1929 \\
\hline Hungary & 1932 & 111.8 & 10.2 & 1932 \\
\hline India & 1938 & 112.6 & 9.9 & 1932 \\
\hline Poland & 1933 & 114.0 & None & None \\
\hline Australia & 1931 & 115.7 & 3.1 & 1929 \\
\hline Belgium & 1932 & 116.2 & 0.2 & 1932 \\
\hline Greece & 1932 & 117.5 & 38.8 & 1931 \\
\hline United Kingdom & 1931 & 118.3 & None & None \\
\hline Korea & 1932 & 120.2 & None & None \\
\hline France & 1932 & 138.9 & None & None \\
\hline Canada & 1933 & 149.0 & 11.9 & 1933 \\
\hline Portugal & 1936 & 151.9 & 3.9 & 1930 \\
\hline Sweden & 1933 & 152.3 & None & None \\
\hline Netherlands & 1934 & 154.2 & 3.6 & 1934 \\
\hline Italy & 1934 & 178.5 & 31.1 & 1929 \\
\hline United States & 1933 & 191.6 & 2.1 & 1933 \\
\hline Median & & 111.3 & & \\
\hline Standard deviation & & 31.9 & & \\
\hline
\end{tabular}

Sources: Mitchell (2003a, 2003b, 2003c); Reinhart and Rogoff (2009) and sources cited therein; and authors' calculations.

a. Central government only.

1932 and then under Roosevelt in 1934 and 1936. Contrary to the popular perception, Hoover did significantly enlarge the role of government. ${ }^{16}$ In contrast, the governments of the United Kingdom and the Nordic countries

16. Akerlof and Shiller (2009) applaud the aggressiveness of both Hoover and Roosevelt but lament the unevenness of their policies. 
Figure 4. Real Government Spending for Selected Country Groups, 1929-38

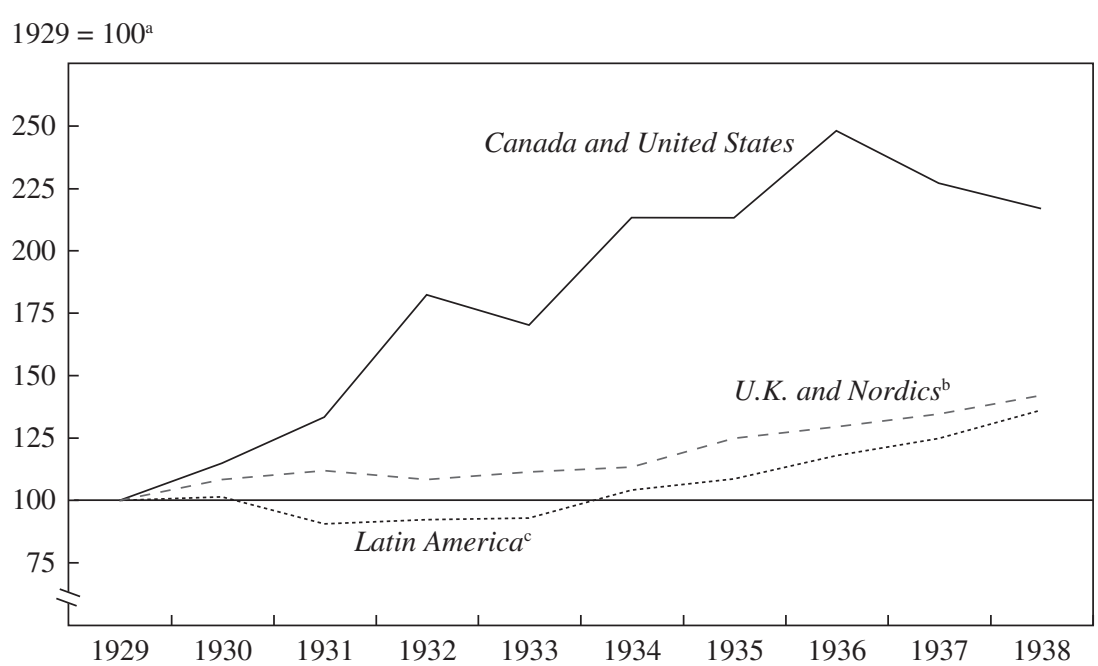

Sources: Mitchell (2003a, 2003b, 2003c); Reinhart and Rogoff (2009) and sources cited therein; and authors' calculations.

a. Each index is calculated from the simple unweighted average for the countries in the group. Spending is central government spending only.

b. Nordics are Finland, Norway, and Sweden.

c. Argentina, Brazil, Chile, Colombia, Mexico, Peru, Uruguay, and Venezuela.

provided less impetus, and fiscal policy in the Latin American countries was decidedly procyclical until 1934 . The last group was no doubt hampered by a lack of access to funding, as well as institutional problems evident in Argentina and Brazil, among other countries.

Although fiscal impetus was forceful in some countries, in almost all it was also erratic. Figure 4 further reveals that each of the three large increases in spending in the United States and Canada was followed by some retrenchment. The impetus from government spending in the United States in 1932, 1934, and 1936 appeared on track to provide considerable lift to the economy, but after each of those years real spending dropped off, imparting an arithmetic drag on expansion. The fact that fiscal expansion has been aggressive in many countries in 2009 works to help contain the contraction in the global economy. That it will continue to do so is far from assured, if history is any guide.

Table 5 examines the ebbs and flows of real government spending across countries from 1929 to 1939. The first column reports the most conventional measure of spending volatility, the standard deviation of annual percentage 
Table 5. Volatility of and Reversals in Real Government Spending in Selected Countries, 1929-39

\begin{tabular}{|c|c|c|c|c|}
\hline Country & $\begin{array}{c}\text { Standard } \\
\text { deviation } \\
\text { of annual } \\
\text { changes in real } \\
\text { government } \\
\text { spending } \\
\text { (percent) }\end{array}$ & $\begin{array}{l}\text { Amplitude } \\
\text { of largest } \\
\quad \text { fiscal } \\
\text { reversal }^{\mathrm{a}} \\
\text { (percentage } \\
\text { points) }\end{array}$ & $\begin{array}{l}\text { Year of } \\
\text { largest } \\
\text { reversal }\end{array}$ & $\begin{array}{c}\text { No. of } \\
\text { reversals with } \\
\text { amplitude }>10 \\
\text { percentage } \\
\text { points }\end{array}$ \\
\hline Italy & 105.4 & 227.7 & 1937 & 3 \\
\hline Greece & 61.3 & 159.2 & 1931 & 3 \\
\hline Peru & 45.0 & 64.8 & 1929 & 5 \\
\hline United States & 33.8 & 47.5 & $1933,1935^{\mathrm{b}}$ & 3 \\
\hline Brazil & 31.5 & 55.0 & 1933 & 5 \\
\hline Finland & 30.6 & 33.0 & 1929 & 4 \\
\hline Portugal & 29.7 & 66.6 & 1937 & 2 \\
\hline Japan & 28.9 & 42.3 & 1937 & 4 \\
\hline Chile & 27.6 & 51.5 & 1929 & 4 \\
\hline Colombia & 27.6 & 68.0 & 1929 & 3 \\
\hline Venezuela & 24.7 & 46.8 & 1929 & 4 \\
\hline France & 21.5 & 15.1 & 1936 & 2 \\
\hline Germany & 21.2 & 21.5 & 1929 & 2 \\
\hline Canada & 16.6 & 39.9 & 1933 & 2 \\
\hline Sweden & 16.5 & 31.4 & 1934 & 2 \\
\hline Austria & 16.4 & 18.5 & $1931,1932^{\mathrm{b}}$ & 3 \\
\hline Uruguay & 16.4 & 24.1 & 1929 & 2 \\
\hline Argentina & 15.2 & 21.2 & 1935 & 3 \\
\hline Netherlands & 12.5 & 20.7 & 1932 & 3 \\
\hline Mexico & 12.0 & 24.4 & 1937 & 1 \\
\hline Korea & 11.9 & 16.6 & 1932 & 3 \\
\hline Netherlands East Indies & 11.7 & 30.3 & 1938 & 1 \\
\hline India & 10.0 & 13.5 & 1931 & 2 \\
\hline Hungary & 9.6 & 20.1 & 1932 & 1 \\
\hline United Kingdom & 9.0 & 12.8 & 1933 & 1 \\
\hline Norway & 8.6 & 11.9 & 1933 & 1 \\
\hline Poland & 7.8 & 12.8 & 1937 & 1 \\
\hline Australia & 7.2 & 11.8 & 1932 & 1 \\
\hline New Zealand & 6.5 & 8.9 & 1932 & 0 \\
\hline
\end{tabular}

Sources: Mitchell (2003a, 2003b, and 2003c); Reinhart and Rogoff (2009) and sources cited therein; authors' calculations.

a. A reversal is defined as a year of rising followed by a year of declining government spending; the amplitude of a reversal is calculated as growth in year $t$ minus growth in year $t+1$. For instance, if real spending rose by 15 percent in year $t$ and declined by 12 percent in the following year, the amplitude would be $15-(-12)=27$ percentage points.

b. Reversals in the two years were comparable in amplitude. 
changes in spending. Fiscal policy was indeed volatile in this period, with six countries posting a standard deviation of spending of more than 30 percent. A second indicator of the inconsistency of fiscal policy is the frequency with which government spending sharply reverses course. We calculate the "amplitude" of such a reversal as the sum of the percentage changes in spending in two consecutive years in which the first year sees a rise in spending and the second a decline. The second column of table 5 reports the amplitude of the largest such reversal in real spending growth for each country, the third lists the year of that reversal, and the fourth reports the number of times such reversals exceeded 10 percentage points in amplitude. Again and again, fiscal policy lacked follow-through in providing consistent impetus. Every one of the countries in the table experienced a reversal of real spending in at least one year of the decade, and all but one country suffered at least one reversal with an amplitude of more than 10 percentage points.

This volatility of fiscal spending could, in principle, have blunted some of the force of the fiscal impetus if it rendered economic planning more

Table 6. Regressions Explaining the Depth and Duration of the Great Depression by Volatility of Government Spending, 1929-39a

\begin{tabular}{|c|c|c|c|c|c|c|}
\hline \multirow{2}{*}{$\frac{\text { Independent variable }}{\text { Constant }}$} & \multicolumn{2}{|c|}{$\begin{array}{l}\text { Dependent } \\
\text { variable: } \\
\text { Peak-to-trough } \\
\text { decline in } \\
\text { real GDP } \\
\text { (percent) }\end{array}$} & \multicolumn{2}{|c|}{$\begin{array}{l}\text { Dependent } \\
\text { variable: } \\
\text { Years until } \\
\text { return to } \\
\text { precrisis level }\end{array}$} & \multicolumn{2}{|c|}{$\begin{array}{c}\text { Dependent } \\
\text { variable: } \\
\text { Growth in real } \\
\text { GDP per capita, } \\
\text { 1929-37 }\end{array}$} \\
\hline & $\begin{array}{c}14.22 \\
(11.42)\end{array}$ & $\begin{array}{l}25.15 \\
(11.26)\end{array}$ & $\begin{array}{r}10.51 \\
6.56\end{array}$ & $\begin{array}{l}9.88 \\
(7.15)\end{array}$ & $\begin{array}{l}-2.32 \\
14.05\end{array}$ & $\begin{array}{c}-7.51 \\
(15.83)\end{array}$ \\
\hline $\begin{array}{l}\text { Annual change in real } \\
\text { government spending } \\
\text { divided by its standard } \\
\text { deviation }^{\mathrm{b}}\end{array}$ & $\begin{array}{c}1.49 \\
(7.71)\end{array}$ & $\begin{array}{c}-9.50 \\
(7.90)\end{array}$ & $\begin{array}{r}-0.83 \\
4.42\end{array}$ & $\begin{array}{l}-1.58 \\
(5.01)\end{array}$ & $\begin{array}{l}5.64 \\
9.48\end{array}$ & $\begin{array}{c}11.86 \\
(11.10)\end{array}$ \\
\hline Dummy for Axis power & & $\begin{array}{c}3.38 \\
(5.70)\end{array}$ & & $\begin{array}{l}-0.75 \\
(3.62)\end{array}$ & & $\begin{array}{c}-4.72 \\
(8.01)\end{array}$ \\
\hline Dummy for Latin America & & $\begin{array}{l}15.54 \\
(4.91)\end{array}$ & & $\begin{array}{c}3.61 \\
(3.11)\end{array}$ & & $\begin{array}{r}-9.63 \\
(6.90)\end{array}$ \\
\hline $\begin{array}{l}\text { Dummy for British } \\
\text { Commonwealth }\end{array}$ & & $\begin{array}{c}3.05 \\
(5.21)\end{array}$ & & $\begin{array}{c}5.19 \\
(3.30)\end{array}$ & & $\begin{array}{l}-4.14 \\
(7.32)\end{array}$ \\
\hline Adjusted $R^{2}$ & 0.00 & 0.29 & 0.00 & 0.14 & 0.01 & 0.09 \\
\hline $\begin{array}{l}\text { Standard error of the } \\
\text { regression }\end{array}$ & 11.04 & 9.83 & 6.33 & 6.24 & 13.57 & 13.82 \\
\hline
\end{tabular}

Source: Authors' regressions.

a. Sample consists of 30 countries in all regressions. Numbers in parentheses are standard errors.

b. Sample covers 1929-39. 
difficult. Table 6 examines the extent to which such a mechanism was at work: using data from a sample of 30 countries from 1929 to 1939, the table reports regressions that attempt to explain the variation in the depth and duration of the business cycle with a measure of the growth of real government spending standardized by its volatility; to be precise, it is the average annual change in real government spending from 1929 to 1939, divided by its standard deviation. These regressions were performed with and without dummy variables for regions and for whether the country was an Axis power; the regressions including the dummy variables also include the logarithms of real GDP per capita and population in 1928, to capture any effects of country size.

As is evident from the first pair of regressions, the depth of the cycle appears unrelated to the volatility of government spending. However, the remaining regressions at least produce coefficients that match the intuition. Higher standardized spending hastened the return of output to precrisis levels and added to real GDP growth. However, the standard deviation of spending is in the denominator of that explanatory variable, implying that greater volatility of real government spending tended to delay economic recovery and to reduce the net change in real GDP per capita. Thus, there may have been real costs associated with policy wavering.

\section{Some Lessons}

Unconventional monetary policy and aggressive fiscal policy were used extensively in the 1930s, in a considerable number of countries. They were not, however, employed consistently. Monetary policy was hampered by beggar-thy-neighbor problems as countries devalued relative to gold at different times and by different amounts. As a consequence, countries derived less benefit from exiting the gold standard than they could have, if indeed they saw any benefit at all. The United States was in the vanguard of aggressive use of fiscal policy at the central government level, but there and in many other countries this fiscal impetus was partly reversed soon after. The net effect was to raise volatility-and therefore uncertainty-and potentially to lessen the stimulus provided.

A message from the 1930s is that national authorities must recognize that the openness of the global economy sometimes works to blunt the effectiveness of policy in one country. In the 2000s the $N+1$ currency has been the U.S. dollar, whose special reserve-currency status meant that the United States received flight-to-safety flows even as it was the epicenter of 
the financial crisis. ${ }^{17}$ Like the appreciating U.S. dollar in the first part of the 1930s, this flight to the safe haven by capital holders outside the United States, by bolstering the dollar, augments the forces of restraint at home.

Such a force may strengthen the case for concerted fiscal stimulus, but here an unpleasant reality intrudes: financial markets do not view all countries alike. Some have a history of uncertain repayment of their debt. Indeed, as shown by Reinhart, Rogoff, and Miguel Savastano (2003), some countries are "debt intolerant" and tend to default at debt-to-income ratios that elsewhere would be an entry ticket to European Monetary Union under the Maastricht Treaty. Progress in institution building has been significant in many of these emerging market economies. But national authorities take that lingering lack of acceptance very seriously and are unlikely to act in a fashion that threatens a reminder of earlier excesses. This implies that the advanced economies may be the only agents with significant scope for fiscal stimulus during a global crisis. ${ }^{18}$

ACKNOWLEDGMENTS We have benefited from the comments of our discussants, the editors, other participants at the Brookings Panel conference, and Kenneth Rogoff. We also thank Meagan Berry, Adam Paul, and Gregory Howard for their assistance.

17. We raised this point in Reinhart and Reinhart (2008) when we asked whether the United States was "too big to fail." Note the parallel with the discussion of the Federal Reserve's failure in the early 1930s. Policymakers need to recognize that safe-haven flows increase demand, necessitating even greater increases in supply.

18. Another reason the advanced economies may have to shoulder more of the burden is systematic differences in fiscal multipliers across the North and the South, as discussed in Ilzetzki, Mendoza, and Végh (2009). 


\section{References}

Akerlof, George A., and Robert J. Shiller. 2009. Animal Spirits: How Human Psychology Drives the Economy, and Why It Matters for Global Capitalism. Princeton University Press.

Barro, Robert J., and José F. Ursúa. 2008. "Macroeconomic Crises since 1870.” $B P E A$, no. 1: 255-350.

Bernanke, Ben S. 2004. Essays on the Great Depression. Princeton University Press.

Bernanke, Ben S., and Vincent R. Reinhart. 2004. "Conducting Monetary Policy at Very Low Short-Term Interest Rates.” American Economic Review 94, no. 2: 85-90.

Board of Governors of the Federal Reserve System. 1943. Banking and Monetary Statistics, 1890-1941. Washington.

Cagan, Phillip. 1965. Determinants and Effects of Changes in the Stock of Money, 1875-1960. Columbia University Press.

Calvo, Guillermo A., and Carmen M. Reinhart. 2002. "Fear of Floating." Quarterly Journal of Economics 117, no. 2: 379-408.

Choudhri, Ehsan U., and Levis A. Kochin. 1980. "The Exchange Rate and the International Transmission of Business Cycle Disturbances: Some Evidence from the Great Depression." Journal of Money, Credit and Banking 12, no. 4, part 1: 565-74.

Eichengreen, Barry. 1992. Golden Fetters: The Gold Standard and the Great Depression 1919-1939. Oxford University Press.

Eichengreen, Barry, and Kevin H. O'Rourke. 2009. "A Tale of Two Depressions.” VoxEU (June). www.voxeu.org/index.php?q=node/3421.

Eichengreen, Barry, and Jeffrey Sachs. 1985. "Exchange Rates and Economic Recovery in the 1930s." Journal of Economic History 45, no. 4: 925-46.

—. 1986. "Competitive Devaluation and the Great Depression: A Theoretical Reassessment." Economics Letters 22, no. 1: 67-71.

Eichengreen, Barry, and Peter Temin. 2000. "The Gold Standard and the Great Depression." Contemporary European History 9, no. 2: 183-207.

Friedman, Milton, and Anna Jacobson Schwartz. 1963. A Monetary History of the United States, 1867-1960. Princeton University Press.

Hamilton, James D. 1988. "The Role of the International Gold Standard in Propagating the Great Depression.” Contemporary Policy Issues 6, no. 2: 67-89.

Hsieh, Chang-Tai, and Christina D. Romer. 2006. "Was the Federal Reserve Constrained by the Gold Standard During the Great Depression? Evidence from the 1932 Open Market Purchase Program." Journal of Economic History 66, no. 1: 140-76.

Ilzetzki, Ethan, Enrique Mendoza, and Carlos Végh. 2009. "How Big (Small) Are Fiscal Multipliers?" University of Maryland.

James, Harold. 2009. The Creation and Destruction of Value. Harvard University Press. 
Kaminsky, Graciela L., Carmen M. Reinhart, and Carlos A. Végh. 2005. "When It Rains, It Pours: Procyclical Capital Flows and Policies.” In NBER Macroeconomics Annual 2004, edited by Mark Gertler and Kenneth Rogoff. MIT Press.

Maddison, Angus. 2004. Historical Statistics for the World Economy: 1-2003 AD. Paris: Organisation for Economic Co-operation and Development. www.ggdc. net/maddison/.

Meltzer, Allan H. 2003. A History of the Federal Reserve, Volume 1: 1913-1951. University of Chicago Press.

Mitchell, Brian R. 2003a. International Historical Statistics: Africa, Asia, and Oceania, 1750-2000. London: Palgrave Macmillan.

- 2003b. International Historical Statistics, Europe, 1750-2000. London: Palgrave Macmillan.

- 2003c. International Historical Statistics: The Americas, 1750-2000. London: Palgrave Macmillan.

Mundell, Robert A. 1968. International Economics. New York: Macmillan.

Nurkse, Ragnar. 1944. International Currency Experience: Lessons of the Interwar Period. Geneva: League of Nations.

Officer, Lawrence H. 2001. “Gold Standard.” In EH.Net Encyclopedia, edited by Robert Whaples (October 1). eh.net/encyclopedia/article/officer.gold.standard.

Orphanides, Athanasios. 2004. "Monetary Policy in Deflation: The Liquidity Trap in History and Practice." North American Journal of Economics and Finance 15, no. 1: 101-24.

Reinhart, Carmen M., and Vincent R. Reinhart. 2008. "Is the US Too Big to Fail?" VoxEU (November). www.voxeu.org/index.php?q=node/2568.

Reinhart, Carmen M., and Kenneth S. Rogoff. 2009. This Time Is Different: Eight Centuries of Financial Folly. Princeton University Press.

Reinhart, Carmen M., Kenneth S. Rogoff, and Miguel A. Savastano. 2003. "Debt Intolerance." BPEA, no. 1: 1-62.

Romer, Christina D. 1992. "What Ended the Great Depression?" Journal of Economic History 52, no. 4: 757-84.

Svensson, Lars E. O. 2003. "Escaping from a Liquidity Trap and Deflation: The Foolproof Way and Others." Journal of Economic Perspectives 17, no. 4: 145-66. 


\section{Comment and Discussion}

\section{COMMENT BY}

CHANG-TAI HSIEH Why did monetary policymakers fail to stem the Great Depression of the 1930s? A conventional view, largely due to Barry Eichengreen and Jeffrey Sachs (1986) and Ben Bernanke (2004), holds that the gold standard was key. Adherence to the gold standard forced economies experiencing capital outflows to contract and was the key mechanism by which deflation was spread throughout the world. The link to gold also prevented central banks from acting as the lender of last resort when faced with a financial panic, and it placed constraints on fiscal authorities who might otherwise have engaged in expansionary spending or tax policies. A key stylized fact that supports this interpretation is that among the industrialized countries, the depth and length of the depression were correlated with how long a country stayed on the gold standard. The downturn was more muted in countries, such as the United Kingdom, that were among the first to exit the gold standard, and longer in countries, such as France, that were among the last.

This paper by Carmen Reinhart and Vincent Reinhart challenges this interpretation of the role of the gold standard by marshalling new facts. Figure 2 of their paper shows that the statistical relationship between the date of exit from the gold standard and the magnitude of the depression disappears when the sample is broadened beyond the industrialized countries. For example, several countries that were mainly primary commodity producers were among the first to leave the gold standard (most of them in 1929, two full years before the United Kingdom's departure in 1931), yet suffered some of the worst downturns. If one interprets this finding as evidence that adherence to the gold standard did not affect the depth and severity of the Great Depression, it potentially changes the standard interpretation of its causes. The question is whether this reinterpretation is warranted. 
In fact, the authors provide two interpretations of their new finding. First, they argue that it shows that departure from the gold standard is less effective "when the global pie is shrinking." Although this interpretation might be correct, the paper presents no evidence to support it. If the global pie was shrinking, by definition it was shrinking for industrialized and nonindustrialized countries alike. Why, then, might such a decline weaken the effectiveness of exiting the gold standard more for the latter than for the former? For example, is a larger share of manufacturing output in the nonindustrialized countries exported, making these countries more susceptible to downturns in world export markets? More generally, does the response to exiting the gold standard differ depending on whether a country is more or less dependent on world trade? Or is the argument that the nonindustrialized countries specialize largely in commodities, whose price elasticity of demand is less than that of other goods? In that case, what might be driving the results is that the output elasticity to changes in the terms of trade for the nonindustrialized countries is not the same as that for the industrialized countries.

The second interpretation offered by the paper harkens back to the argument by Ragnar Nurkse (1944). In brief, the argument is that one country's departure from the gold standard might not necessarily translate into a decline in the terms of trade if other countries are depreciating against that country's currency at the same time. (As an aside, it would be useful if the paper couched the discussion in terms of the real exchange rate, that is, net of changes in domestic prices or wages on both sides.) Again, here it would be useful to know how exactly this interpretation fits with the observation that departure from the gold standard was associated with economic recovery in industrialized but not in nonindustrialized countries. The paper emphasizes the fact that exchange rate adjustment in most countries came largely at the expense of the United States. This may well be true for 1931 and 1932, but the United States' departure from the gold standard in 1933 was quickly followed by a recovery. The paper needs to show that departure from the gold standard was associated with depreciation for the industrialized countries and not for the nonindustrialized countries. A casual reading of figure 3 suggests that the evidence on this point is not clear. Over all, the European countries (other than the United Kingdom and the Nordic countries) did see their currencies depreciate relative to the U.S. dollar. The Canada-U.S. exchange rate, however, was basically unchanged. The pound sterling actually appreciated against the U.S. dollar, yet this was the country where the downturn was the smallest. On the other hand, the Latin American currencies saw the largest depreciation against 
the U.S. dollar, yet these were the countries where the downturn was most severe.

Let me propose a third explanation. To interpret the correlation between the timing of exit from the gold standard and subsequent economic outcomes as causal, one needs to be sure that the cross-country variation in the timing of the exit from gold is not driven by forces that might also drive the economic outcomes one is measuring. In his book Golden Fetters (1992), Barry Eichengreen provides a wealth of narrative evidence that the degree of commitment to the gold standard among the industrialized countries was largely driven by ideology and domestic political considerations. Although these political forces might also have an independent effect on economic policy (that is, other than through their effect on exchange rate policy), this is not the same as a story where, for example, countries that exited the gold standard, or exited sooner, were the ones that were hit the hardest by adverse economic shocks. And the argument that variation in the degree of commitment to the gold standard is exogenous to economic forces is less plausible for the nonindustrialized than for the industrialized countries. For example, isn't the fact that Argentina, Brazil, Australia, New Zealand, Uruguay, and Venezuela (table 2 in the paper) were the first countries to exit the gold standard driven by the severe decline in world prices for their exports? If so, then how does one disentangle the effect of the decline in export prices from the effect of exit from the gold standard? It might well be the case that the exit from the gold standard stimulated output, but this effect is overwhelmed by the economic shocks that prompted the country to exit the gold standard in the first place.

In sum, the new facts presented by Reinhart and Reinhart have the potential to overturn what we thought we knew about the causes of the Great Depression. But much more needs to be done to show that their interpretation of their new facts-that the timing of departure from the gold standard did not contribute to recovery from the Great Depressionis the right one.

\section{REFERENCES FOR THE HSIEH COMMENT}

Bernanke, Ben S. 2004. Essays on the Great Depression. Princeton University Press.

Eichengreen, Barry. 1992. Golden Fetters: The Gold Standard and the Great Depression 1919-1939. Oxford University Press.

Eichengreen, Barry, and Jeffrey Sachs. 1985. "Exchange Rates and Economic Recovery in the 1930s." Journal of Economic History 45, no. 4: 925-46.

Nurkse, Ragnar. 1944. International Currency Experience: Lessons of the Interwar Period. Geneva: League of Nations. 
GENERAL DISCUSSION Linda Goldberg thought it worth recalling the specific circumstances in which exchange rate changes can make a difference toward recovery from a recession. The classic mechanism is expenditure switching: changes in exchange rates change the relative prices of goods in different countries. But the amount by which such changes help a country in recession depends in part on the degree to which production is vertically integrated. The proportion of U.S. imports that consists of components and raw commodities rather than final goods for consumption is higher today than in the past, and this limits the effects that one can expect through the exchange rate channel. Goldberg also suggested introducing financial globalization variables into the analysis. For example, there is evidence that the more globalized banks are less sensitive to U.S. monetary policy than other banks, because the globalized banks are able to transfer liquidity among their different subsidiaries. This does not make monetary policy completely ineffective, but it does shift the incidence of monetary policy to those countries that are host to the global counterparties in these intrafirm capital transactions.

Alan Auerbach pointed out that state and local spending was a much larger share of U.S. government spending in the 1930s than it is today. In the current recession, state and local government responses have tended to be procyclical, and this effect needs to be taken into account. Auerbach also observed that the paper dealt only with government spending, and he suggested looking at the tax policy response to the recession in different countries as well. Finally, he wondered to what extent recent fiscal policy actions in different countries have been expressly designed to avoid international leakages, perhaps in response to the greater openness of economies in general. 